\title{
Paideusis
}

\section{Diversity and Teaching: Teacher Education Yearbook (Yearbook of the Association of Teacher Education) (Mary John O'Hair and Sandra J. Odell (Eds.))}

\section{Murray Elliott}

Volume 9, Number 2, 1996

URI: https://id.erudit.org/iderudit/1073246ar

DOI: https://doi.org/10.7202/1073246ar

See table of contents

Publisher(s)

Canadian Philosophy of Education Society

ISSN

0838-4517 (print)

1916-0348 (digital)

Explore this journal

Cite this review

Elliott, M. (1996). Review of [Diversity and Teaching: Teacher Education Yearbook (Yearbook of the Association of Teacher Education) (Mary John O'Hair and Sandra J. Odell (Eds.))]. Paideusis, 9(2), 38-39.

https://doi.org/10.7202/1073246ar 
Mary John O'Hair and Sandra J. Odell (eds.), Diversity and Teaching: Teacher Education Yearbook (Yearbook of the Association of Teacher Educators). Orlando, FL: Harcourt Brace Jovanovich, 1993.

When I first attended the annual conference of the Association of Teacher Educators, I was impressed with the good sense talked in many sessions. I was especially taken by the unpretentious way in which theoretical research studies were discussed in the context of a shared commitment to improving teaching and learning in schools. One could not miss the fact that a scholarly community was talking primarily with -not to, at or about-practising teachers.

A decade later, this same ideal has spawned what I hope will be a series of yearbooks of the ATE in which selected research reports from each annual meeting will be available in a form in which the import of this research is interpreted in relation to its significance, not just for the so-called scholarly community, but for schools and teachers as well.

The present volume arises from the 1993 ATE conference which had "diversity" as its theme. The book has three declared interrelated objectives: first, "to present current research on the topic of diversity and teaching in a meaningful way for teachers and teacher educators;" second, "to apply new knowledge on diversity and teaching to classrooms;" and third, "to provide a reflective approach to understanding research related to diversity and teaching" (pp. xi-xii). The editors, Mary John O'Hair and Sandra Odell, are wellpositioned to give shape to a volume with these objectives. Both have had a long involvement in teacher education, the former with a special interest in preparing teachers for inner city schools and the latter with rich experience in working collaboratively with teachers in mentoring and teacher induction.

Together, they have devised an interesting and potentially fruitful plan for giving scholarly and professional shape to the book. The fourteen papers selected are grouped around four themes: contexts for teaching, processes in studying teaching, perspectives on communication, and issues in school curricula. The editors have enlisted scholars with expertise in each of these areas to write introductory overviews and concluding reflections about the scholarly and professional significance of the papers in that group. The editors themselves have written an introduction to the book as a whole.

As the book unfolds, the theme of diversity and teaching comes to take on a diversity of interpretations. This is both a decided strength of the book, and also a distinct weakness. At the same time, this diversity of diversities both helps the reader to transcend any preconceived limiting perspectives and also contributes to a growing diffuseness as the four main sections open quite different areas of the theme. The limitations of an overall partial focus are replaced by the limitations of bow little can be done in each of the four theme areas within a single book.

Let me illustrate by referring to the first theme, diverse contexts for teaching. The four papers included in this section highlight such features of the social context as urban schools and poverty, violence and abuse, trust and its nature, cultural pluralism and cultural awareness, and intra-school politics and power. These are all important concerns that need to be addressed by teachers and teacher educators in Canada as well as the US, though perhaps differently because of differing regional particularities. However, equally momentous contex- 
tual features are not covered in the selected papers. Religious diversity, always significant throughout North America, is increasingly becoming fundamental to a variety of organizational and curricular policies, and the inclusion of a paper related to the significance of religious diversity would have strengthened the book. Similarly, especially in the US but in Canada as well, the "common school" ideal is increasing breaking down as a result of such thrusts as charter schools and commercial providers of education and schooling. These sorts of contextual factors have enormous potential to alter teaching and learning, and not dealing with them is a significant limitation of the book.

Similarly, although a diversity of approaches is represented in the papers in the section on diverse processes in studying teaching, other relevant types of inquiry are noticeably absent. Inquiry approaches of the selected studies include self-analysis, analysis of written and videotaped records of classroom cases, controlled experiment with quantitative analysis, and qualitative analysis of written responses to set stimuli. Absent from this theme are examples of historical and conceptual analysis, both of which, from the differing perspectives of the disciplines of history and philosophy, have rich potential for portraying and clarifying images, ideals, and possibilities for teaching. I do not wish to deny the value of the kinds of studies the editors have selected, but rather to underline the comment of the writers of the "reflection" on these studies that teaching is a complex phenomenon and we need "multiple approaches to investigate" this complexity (p. 156). The book is valuable as it stands, but it would have been strengthened by including samples of these additional modes of studying teaching.

I fully appreciate that within a single volume of manageable proportions not everything can be included. Selections must be made, and in the case of a conference-based yearbook, the editors are restricted to selecting from the conference papers. Perhaps for this reason, the resulting book includes several themes but a limited range of reports within each theme. I have suggested value in the opposite approach: less diversity of themes and greater diversity within each of these.

Are the editors wrong to have developed the book as they have done? Not at all. They have produced a volume of great value to teachers and teacher educators who seek to know about and to discern the significance of current research for classroom practice. I would like to have seen fuller and more comprehensive treatments of the important themes of the book. Perhaps-and hopefully - that will come with future yearbooks from the ATE.

Reviewed by Murray Elliott, University of British Columbia 